\title{
| ITS2 REGION-BASED MOLECULAR IDENTIFICATION OF FUNGAL PATHOGENS IN EQUINE CORNEAL ULCERATION
}

\author{
| MAHA I. HAMED; HAROON MOHAMMAD ** WENDY TOWNSEND ${ }^{* * *}$ and MOHAMED \\ N. SELEEM ${ }^{* *}$ \\ *Department of animal medicine (Infectious Diseases) Faculty of veterinary Medicine, Assiut University, Egypt \\ ${ }^{* * *}$ Department of Comparative Pathobiology, College of Veterinary Medicine, Purdue University, West Lafayette, USA \\ ${ }^{* * * *}$ Department of Veterinary Clinical Sciences, College of Veterinary Medicine, Purdue University, West Lafayette, USA \\ Email: mahohzero@gmail.com
}

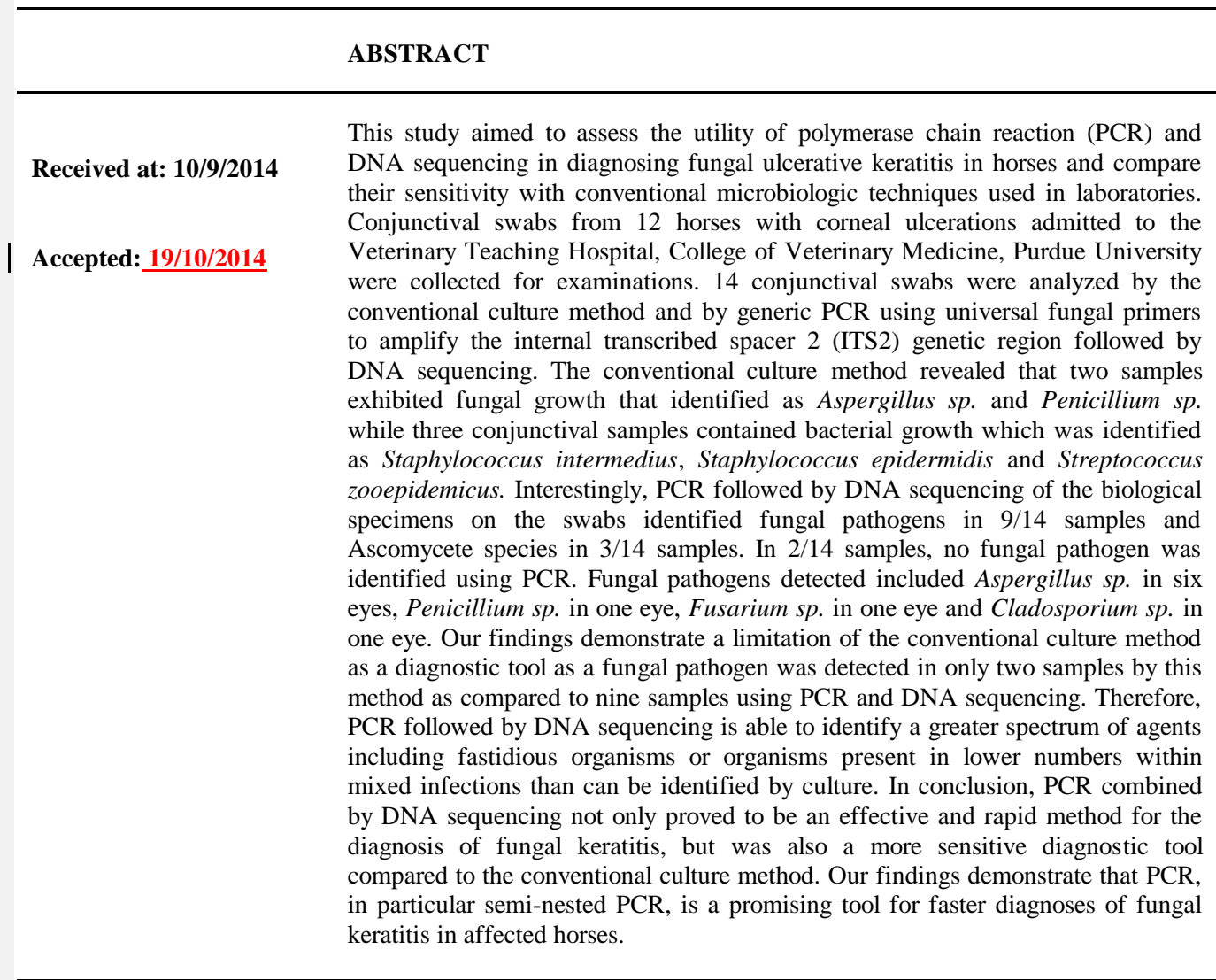

\section{INTRODUCTION}

Keratitis is one of the most frequent ophthalmic conditions that impacts horses (Nasisse and Nelms 1992, Hamor and Whelan 1999, Brooks and Matthews 2007 and Wada et al., 2010). For many cases, infectious agents can be identified in the affected eye, although confirmation of microbial etiology is usually not possible upon initial clinical inspection (Gaarder et al., 1998). Fungal keratopathies occur in several clinical forms in the horse. Microerosions, superficial and deep corneal ulcers, melting corneal ulcers, stromal plaques, corneal perforation and iris prolapse, and nonulcerative stromal abscesses are recognized ophthalmic diseases caused by fungi in horses (Brooks and Matthews, 2007 and Brooks, 2009). With regards to equine keratomycoses, clinical outcomes can range from rapid keratolysis to the formation of abscesses to blindness in severely affected patients (Wada et al., 2010 and Zeiss et al., 2013).

The higher incidence of keratitis in horses is likely due to both host and environmental factors that 
increase the exposure and susceptibility of the equine cornea to both bacteria and fungi. Mycotic keratitis is estimated to be responsible for upwards of $25 \%$ of all ulcerative keratitis cases reported (Zeiss et al., 2013); it occurs after the creation of a defect in the epithelium as a result of corneal trauma (Andrew and Willis, 2005 and Brooks, 2008). Fungal species most often identified as causative agents of equine keratomycosis include Aspergillus sp., Fusarium sp. and Candida sp. (Gaarder et al., 1998, Andrew and Willis, 2005 and Ledbetter et al., 2007). While Aspergillus sp. and Fusarium sp. are isolated frequently in all studies, Candida $s p$. are reported more often in temperate climates in contrast to tropical climates (Gaarder et al., 1998, Andrew and Willis, 2005, Ledbetter et al., 2007 and Galàn et al., 2009).

Early detection of infection has a significant impact on the clinical outcome of many infectious diseases, including mycotic keratitis. Currently, diagnosis of fungal keratitis relies heavily upon cytology, culturing infected tissues, and histology (Andrew et al., 1998 and Wada et al., 2010). Unfortunately, the identification of fungi by traditional morphologic and metabolic characteristics may take weeks or even months (Turenne et al., 1999). At the molecular level, genetic sequence variation offers an alternative to culturing for detection and identification of fungi. For example, the ribosomal genes demonstrate conserved sequence regions ideal for primer targeting as well as regions of variability useful for species identification Fungal identification utilizes specific primers designed to amplify internal transcribed spacer regions (ITS1 and ITS2) located between conserved genes encoding $18 \mathrm{~S}, 5.8 \mathrm{~S}$, and $28 \mathrm{~S}$ rRNA. Precise identification of the fungal species is subsequently achieved by sequencing the amplified product (Petti, 2007).

The objective of this study was to assess the diagnostic utility of molecular techniques (sequence analysis of PCR-amplified ITS2/5.8S rDNA) for fungal detection of clinical samples obtained from horses with naturally acquired corneal ulcers presenting to the Veterinary Teaching Hospital, College of Veterinary Medicine, Purdue University. The aim of this technique is to reduce the time required for mycological diagnosis, enhance senstivity, and identify the causative fungal agent responsible for the infection (thus permitting appropriate treatment to be administered).

\section{MATERIALS and METHODS}

\section{Animals and samples:}

Swabs from 12 horses with corneal ulcerations admitted to the Veterinary Teaching Hospital, College of Veterinary Medicine, Purdue University were collected for examinations. 36 conjunctival swabs were collected from 12 diseased horses (three swabs from each infected eye). One swab for bacterial culture, one swab for fungal culture and one swab for PCR.

\section{Bacterial and fungal culture:}

One swab from each animal was cultured for aerobic bacteria by streaking on blood agar and McConkey plates, followed by incubation at $35^{\circ} \mathrm{C}$. Bacteria were identified using Gram staining and standard biochemical techniques (Isenberg, 1998). One swab from each animal was cultured for fungi indemnification by plating onto Sabouraud dextrose agar (Remel Microbiology Products Ref. R01766) and potato dextrose agar (Remel Microbiology Products Ref. R01695), incubated at $25{ }^{\circ} \mathrm{C}$ and identified on the basis of morphology 30 following lactophenol cotton blue staining (Chapin, 1995). Bacterial culture was scored as negative after two weeks and fungal culture after four weeks of incubation without visible growth.

\section{Fungal PCR identification:}

1. Sampling and DNA extraction:

12 conjunctival swabs were taken and immediately frozen at $-20^{\circ} \mathrm{C}$ until they were analyzed. The DNA was extracted and purified from each sample by mixing the cotton swabs with $200 \mu \mathrm{l}$ of sterile PBS and $180 \mu \mathrm{l}$ of DNA extraction buffer (DNeasy Blood $\&$ Tissue Kit by Qiagen) and subsequently following the protocol of the manufacturer. DNA was eluted with $100 \mu \mathrm{l}$ of elution buffer and tested for PCR amplifiable DNA.

\section{ITS2 region amplification}

It was suspected that the unknown pathogens were of fungal origin. For this reason, PCR reactions were conducted using universal fungal primers to amplify the internal transcribed spacer 2 (ITS2) genetic region (Figure 1). ITS86 forward primer $5{ }^{\prime}$-GTG AAT CAT CGA ATC TTT GAA C- $3^{\prime}$ and ITS4 reverse primer 5'-TCC TCC GCT TAT TGA TAT GC- 3' were utilized to amplify the ITS2 region of fungal DNA (Turenne et al., 1999). The 26- $\mu 1$ PCR reaction mixture contained $3 \mu \mathrm{l}$ of DNA template, $0.5 \mu \mathrm{l}$ of $100 \mathrm{mM}$ forward and reverse primers, $13 \mu \mathrm{l} \mathrm{GoTaq}{ }^{\circledR}$ Green Master Mix (Promega) and $9 \mu$ l nuclease-free water. The PCR was performed in a Bio-Rad thermal cycler using the following cycle condition: initial denaturing step: 1 cycle at $95^{\circ} \mathrm{C}$ for 5 minutes followed by 40 cycles for the following steps denaturing step: $95^{\circ} \mathrm{C}$ for 30 seconds, annealing step: 55C for 1 minute and extension step: $72^{\circ} \mathrm{C}$ for 1 minute - followed by a final extension step: $72^{\circ} \mathrm{C}$ for 6 minutes.

\section{Agarose gel electrophoresis}

Detection of PCR-amplified product was performed by electrophoresis on a $1 \%(\mathrm{wt} / \mathrm{vol})$ agarose gel 
stained with ethidium bromide. A $1 \mathrm{~kb}$ plus ladder (Invitrogen) was also run in parallel for approximate PCR product band sizing.

4. DNA sequencing of PCR products.

Amplified PCR products were extracted from the gel using a Gel Extraction Kit from Qiagen. The purified unknown DNA fragments were sent for nucleotide sequencing at the Purdue Genomics Facility (ABI 3137XL low-throughput capillary machine) using only the forward primer.

5. Fragment analysis of the ITS2 region

ITS2 rDNA sequences were analyzed by using the BLAST alignment program of the GenBank database (National Institutes of Health) and confirmed using the Saccharomyces Genome Database (Fungal BLAST) (Balakrishnan et al., 2005).

6. Some samples did not give sequences of appropriate length to permit identification by BLAST For these samples, a semi-nested PCR was performed using two sets of primers and two PCR reactions (Ferrer et al., 2001):

A- First round amplification: This reaction was conducted using the ITS 1 forward primer $5^{\prime}$-TCC GTA GGT GAA CCT GCG G-3' and ITS4 reverse primer 5'-TCC TCC GCT TAT TGA TAT GC- 3'. The 50- $\mu \mathrm{l}$ PCR reaction mixture contained $10 \mu \mathrm{l}$ of DNA template, $1 \mu \mathrm{l}$ of $100 \mathrm{mM}$ forward and reverse primers, $25 \mu \mathrm{l}$ GoTaq ${ }^{\circledR}$ Green Master Mix (Promega) and $13 \mu \mathrm{l}$ nuclease-free water. The PCR was performed in a thermal cycler (Bio-Rad) using the following cycle condition: initial denaturing step: 1 cycle at $95^{\circ} \mathrm{C}$ for 5 minutes followed by 35 cycles for the following steps - denaturing step: $95^{\circ} \mathrm{C}$ for 30 seconds, annealing step: $55^{\circ} \mathrm{C}$ for 1 minute and extension step: $72^{\circ} \mathrm{C}$ for 1 minute - followed by a final extension step: $72^{\circ} \mathrm{C}$ for 6 minutes.

B- Second round amplification: This reaction was completed using the ITS86 forward primer 5' -GTG AAT CATCGA ATC TTT GAA C-3' and ITS4 reverse primer $5^{\prime}$-TCC TCC GCT TAT TGA TAT GC- 3 ' to amplify the ITS2 region of fungal DNA

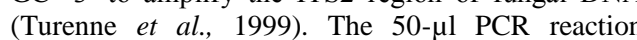
mixture contained $1 \mu \mathrm{l}$ of the first round product, $1 \mu \mathrm{l}$ of $100 \mathrm{mM}$ forward and reverse primers, $25 \mu \mathrm{l}$ GoTaq ${ }^{\circledR}$ Green Master Mix (Promega) and $22 \mu$ nuclease-free water. The PCR was performed in a Bio-Rad thermal cycler using the following cycle condition: initial denaturing step: 1 cycle at $95^{\circ} \mathrm{C}$ for 5 minutes followed by 30 cycles using the following steps - denaturing step: $95^{\circ} \mathrm{C}$ for 30 seconds, annealing step: $55^{\circ} \mathrm{C}$ for 30 seconds and extension step: $72^{\circ} \mathrm{C}$ for 30 seconds, followed by final extension step: $72^{\circ} \mathrm{C}$ for 6 minutes. Then steps $3-5$ were repeated to determine the suspected pathogen.

\section{RESULTS}

\section{Culture results:}

Samples from two eyes were not tested, samples from seven eyes showed no growth, samples from two eyes showed fungal growth which were identified as Aspergillus sp. and Penicillium sp., and three eyes exhibited bacterial growth which were identified as Staphylococcus intermedius, Staphylococcus epidermidis and Streptococcus zooepidemicus (specified in Table 2).

\section{PCR results:}

Detection of the causative pathogen via amplification of the ITS2 region of fungal DNA by conventional PCR resulted in successful identification of the fungal species in 10 conjunctival swabs. A strong band at $280 \mathrm{bp}$ and a long sequence of nucleotides was used to identify the pathogen using the fungal BLAST program (Figure 2). The other four conjunctival swabs presented very weak bands when DNA samples were amplified using conventional PCR; furthermore the short nucleotide sequences generated could not be used to successfully identify pathogens using the fungal BLAST program. This issue was resolved by using seminested PCR which resulted in a very weak band at $550 \mathrm{bp}$ during the first round of PCR for these four samples. In the subsequent round, a clear, distinguishable band at 280 bp was observed and resulted in a suitable nucleotide sequence which permitted the pathogen to be successfully identified using the fungal BLAST program. The only samples where PCR could not be used to identify a fungal pathogen came from samples 8 and 9 (Figure 3). This may be due to the fact that the suspected pathogen in these two samples was of bacterial origin (as confirmed by the conventional culture results presented in Table 2).

A fungal pathogen was identified in nine ocular samples. Ascomycete was identified in three eyes, which is unlikely to be responsible for fungal keratitis, and no organism was successfully identified in two ocular samples. Fungal pathogens detected included Aspergillus sp. in six eyes, Penicillium sp. in one eye, Fusarium sp. in one eye and Cladosporium $s p$. in one eye (Table 1). A comparison between the culture and PCR results are presented in Table 2 
Assiut Vet. Med. J. Vol. 60 No. 143 October 2014

Table 1: Pathogen detected as causative agent for ocular infection in equine patients detected using molecular diagnostics.

\begin{tabular}{|c|c|c|c|}
\hline $\begin{array}{l}\text { No of the patient 1-14 We } \\
\text { can't mention any name that } \\
\text { identifies the patient }\end{array}$ & Pathogen identified & Detailed identification & $\begin{array}{c}\text { \% of } \\
\text { Sequence } \\
\text { Aligned }\end{array}$ \\
\hline 1 & Penicillium sp. & $\begin{array}{c}\text { Penicillium farinosum } \\
\text { Penicillium commune } \\
\text { Penicillium crustosum } \\
\text { Penicillium expansum } \\
\text { Penicillium griseoroseum } \\
\text { Penicillium camemberti } \\
\text { Penicillium } s p . \\
\text { Ascomycete } \text { sp. }\end{array}$ & $\begin{array}{l}98 \% \\
97 \% \\
97 \% \\
97 \% \\
97 \% \\
97 \% \\
97 \% \\
98 \%\end{array}$ \\
\hline 2 & Aspergillus sp. & $\begin{array}{c}\text { Aspergillus flavus } \\
\text { Aspergillus oryzae } \\
\text { Aspergillus sp. } \\
\text { Aspergillus nomius } \\
\text { Aspergillus fischerti } \\
\text { Aspergillus parasiticus } \\
\text { Aspergillus sojae } \\
\text { Aspergillus pseudotamarii }\end{array}$ & $\begin{array}{l}100 \% \\
100 \% \\
100 \% \\
100 \% \\
100 \% \\
100 \% \\
98 \% \\
98 \% \\
\end{array}$ \\
\hline 3 & Aspergillus sp. & $\begin{array}{c}\text { Aspergillus flavus } \\
\text { Aspergillus oryzae } \\
\text { Aspergillus sp. } \\
\text { Aspergillus nomius } \\
\text { Aspergillus parasiticus }\end{array}$ & $\begin{array}{c}100 \% \\
100 \% \\
100 \% \\
99 \% \\
99 \% \\
\end{array}$ \\
\hline 4 & Cladosporium sp. & $\begin{array}{c}\text { Cladosporium sphaerospermum } \\
\text { Davidiella macrospora } \\
\text { Sphaerulina polyspora } \\
\text { Davidiella tassiana } \\
\text { Cladosporium macrocarpum } \\
\text { Cladosporium ossifragi } \\
\text { Cladosporium antarcticum } \\
\text { Cladosporium bruhnei } \\
\text { Cladosporium cf. subtilissimum } \\
\text { Davidiella sp. } \\
\text { Cladosporium cladosporioides } \\
\text { Mycosphaerella macrospora } \\
\text { Cladosporium herbarum } \\
\text { Cladosporium sp. } \\
\text { Choiromyces aboriginum } \\
\text { Cladosporium uredinicola } \\
\text { Dothideomycetes sp. }\end{array}$ & $\begin{array}{l}99 \% \\
99 \% \\
99 \% \\
99 \% \\
99 \% \\
99 \% \\
99 \% \\
99 \% \\
99 \% \\
99 \% \\
99 \% \\
99 \% \\
99 \% \\
99 \% \\
99 \% \\
98 \% \\
98 \%\end{array}$ \\
\hline 5 & Aspergillus sp. & $\begin{array}{c}\text { Aspergillus lentulus } \\
\text { Aspergillus fumigatus } \\
\text { Aspergillus sp. } \\
\text { Aspergillus flavus } \\
\text { Neosartorya fischeri } \\
\text { Ascomycete sp. }\end{array}$ & $\begin{array}{l}99 \% \\
99 \% \\
99 \% \\
97 \% \\
97 \% \\
97 \% \\
\end{array}$ \\
\hline 6 & Aspergillus $s p$. & $\begin{array}{c}\text { Aspergillus lentulus } \\
\text { Antarctic fungal sp. } \\
\text { Aspergillus fumigatus } \\
\text { Aspergillus sp. } \\
\text { Neosartorya fischeri } \\
\text { Ascomycete sp. } \\
\text { Aspergillus flavus } \\
\text { Neosartorya spinosa } \\
\text { Neosartorya hiratsukae } \\
\text { Aspergillus unilateralis } \\
\text { Aspergillus fumisynnematus }\end{array}$ & $\begin{array}{c}99 \% \\
99 \% \\
100 \% \\
99 \% \\
97 \% \\
97 \% \\
97 \% \\
97 \% \\
97 \% \\
97 \% \\
97 \% \\
\end{array}$ \\
\hline 7 & Aspergillus sp. & $\begin{array}{l}\text { Asperagillus lentulus } \\
\text { Aspergillus fumigatus } \\
\text { Antarctic fungal sp. } \\
\text { Aspergillus sp. } \\
\text { Aspergillus flavus }\end{array}$ & $\begin{array}{l}99 \% \\
99 \% \\
99 \% \\
98 \% \\
97 \%\end{array}$ \\
\hline
\end{tabular}

Formatted: Font: (Default) Times New Roman, 12 pt, Bold, Complex Script Font: Times New Roman, 12 pt, Bold

\section{Formatted: Centered}

Formatted: Font: (Default) Times New Roman, 12 pt, Bold, Complex Script Font: Times New Roman, 12 pt, Bold 


\begin{tabular}{|c|c|c|c|}
\hline & & $\begin{array}{c}\text { Neosartorya fischeri } \\
\text { Ascomycete sp. }\end{array}$ & $\begin{array}{l}97 \% \\
97 \% \\
\end{array}$ \\
\hline 8 & $\begin{array}{c}\text { Very short sequence, } \\
\text { organism could not be } \\
\text { identified }\end{array}$ & $\begin{array}{l}\text { Very short sequence, organism could } \\
\text { not be identified }\end{array}$ & \\
\hline 9 & Negative for PCR & Negative & \\
\hline 10 & Fusarium sp. & 205 Fusarium $s p$. & $95 \%$ \\
\hline 11 & Aspergillus sp. & $\begin{array}{c}\text { Aspergillus flavus } \\
\text { Aspergillus oryzae } \\
\text { Aspergillus sp. } \\
\text { Aspergillus nomius } \\
\text { Neosartorya fischeri }\end{array}$ & $\begin{array}{l}100 \% \\
99 \% \\
99 \% \\
99 \% \\
99 \% \\
\end{array}$ \\
\hline 12 & Ascomycete & $\begin{array}{c}\text { Uncultured ascomycete isolate } \\
\text { Dothideomycetes sp. } \\
\text { Coniozyma leucospermi } \\
\text { Hormonema aff. Prunorum } \\
\text { Dothidea berberidis } \\
\text { Tumularia aquatic } \\
\text { Endoconidioma populi } \\
\text { Hormonema carpetanum } \\
\end{array}$ & $\begin{array}{l}100 \% \\
99 \% \\
98 \% \\
97 \% \\
97 \% \\
97 \% \\
98 \% \\
98 \% \\
\end{array}$ \\
\hline 13 & Ascomycete & $\begin{array}{c}\text { Uncultured ascomycete isolate } \\
\text { Dothideomycetes sp. } \\
\text { Coniozyma leucospermi } \\
\text { Hormonema aff. Prunorum } \\
\text { Tumularia aquatic } \\
\text { Endoconidioma populi } \\
\text { Hormonema carpetanum } \\
\end{array}$ & $\begin{array}{l}100 \% \\
98 \% \\
98 \% \\
97 \% \\
97 \% \\
98 \% \\
98 \% \\
\end{array}$ \\
\hline 14 & Ascomycete & $\begin{array}{c}\text { Dothideomycetes sp. } \\
\text { Coniozyma leucospermi } \\
\text { Tumularia aquatica } \\
\text { Endocondioma populi } \\
\text { Fungal sp. } \\
\text { Harmonema carpetanum }\end{array}$ & $\begin{array}{l}97 \% \\
97 \% \\
97 \% \\
97 \% \\
98 \% \\
98 \%\end{array}$ \\
\hline
\end{tabular}

Table 2: Comparison between culture and PCR results.

\begin{tabular}{ccc}
\hline Patient number 1-14 & Culture & PCR \\
\hline 1 & Penicillium sp. & Penicillium sp. \\
\hline 2 & Asperagillus sp. & Asperagillus sp. \\
\hline 3 & No growth & \\
\hline 4 & No growth & Cladosporium sp. \\
\hline 5 & No growth & Asperagillus sp. \\
\hline 6 & No growth & Aspergillus sp. \\
\hline 7 & No growth & Aspergillus sp. \\
\hline 8 & Streptococcus zooepidemicus & Negative \\
\hline 9 & Staphylococcus intermedius & Negative \\
\hline 10 & No growth & Fusarium sp. \\
\hline 11 & No growth & Aspergillus sp.
\end{tabular}




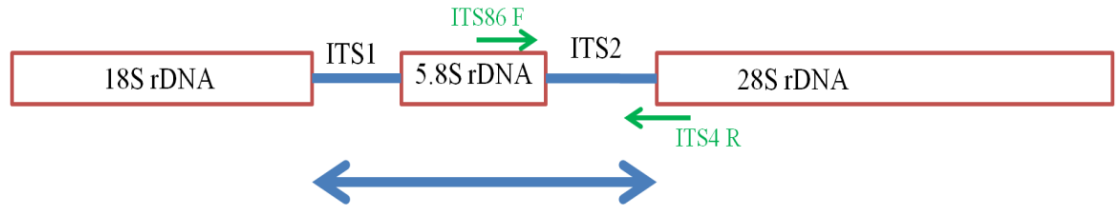

ITS

Figure 1: Schematic representation of the fungal ribosomal genes containing the primer target areas used in the amplification of the ITS2 region.

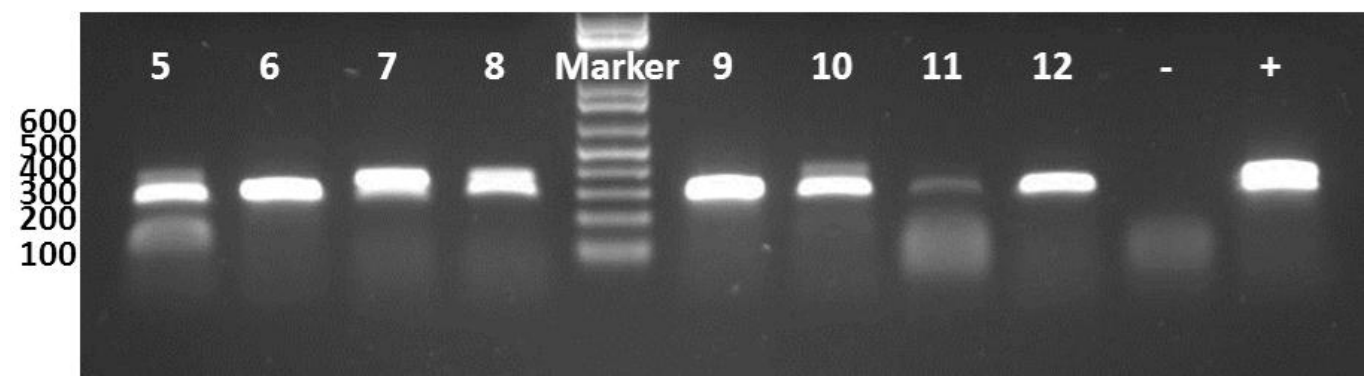

Figure 2: Agarose gel electrophoresis showing PCR products of unknown fungal agents collected by conjunctival swabs from ocular infections in horses. (Samples from 5 to 12, negative control and +: positive control).

FIRST ROUND

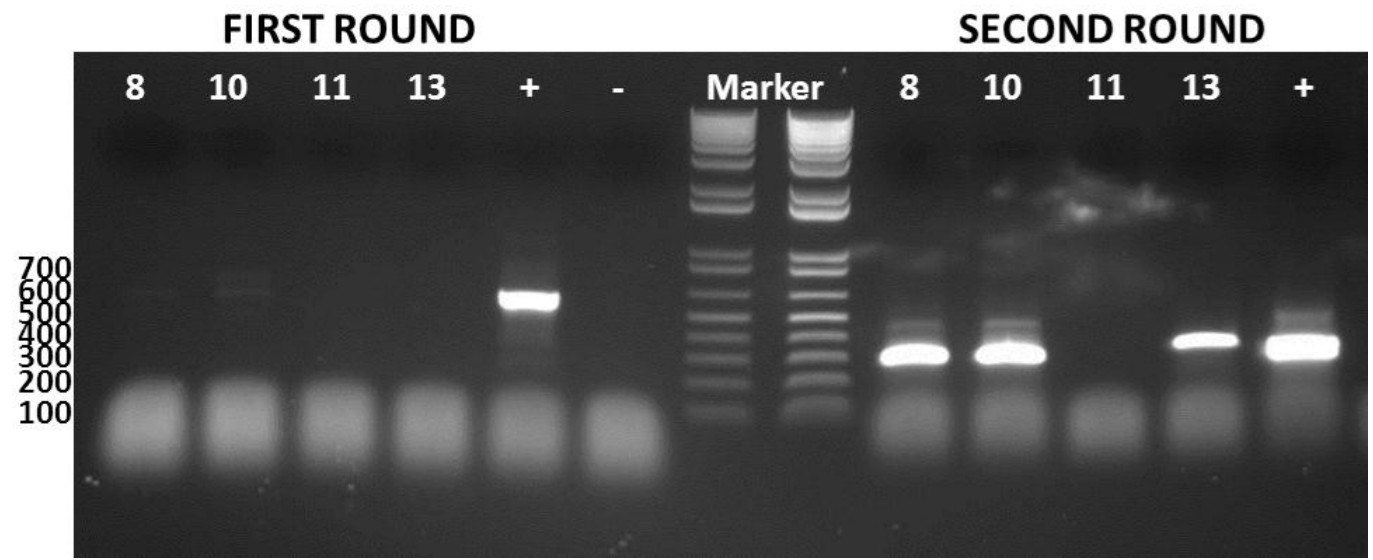

Figure 3: Agarose gel electrophoresis showing seminested PCR products of unknown fungal agents collected by conjunctival swabs from ocular infections in horses. (Samples 8, 10,11, 13, negative control and +: positive control).

\section{DISCUSSION}

The eyes of equine are predisposed to fungal infections due to their exposed position, suspected tear film instability, and the prevalence of fungal organisms in the horse's environment (Samuelson et al., 1984 and Andrew et al., 1998). Keratomycosis is an infection occurring after primary disruption of the corneal epithelium enabling environmental organisms to adhere to the corneal stroma (Samuelson et al., 1984 and Clode, 2011). Fungal hyphae have a tropism to glycosaminoglycans adjacent to the Descemet's membrane (Hamilton et al., 1994 and Clode, 2011). They release proteases and inhibit angiogenesis in the cornea, leading to corneal melting and anterior uveitis (Welch et al., 2000 and Thomas, 2003). The analysis of 14 ocular samples from the present study found that Aspergillus sp. was the most prevalent fungal pathogen present in the samples examined; these results are in agreement with results recorded by Moore et al. (1983). They stated that Aspergillus sp. is the most common fungal pathogen that causes fungal keratitis in horses, and it may lead 
to severe consequences when mixed with a bacterial infection. Culture results from three samples confirmed the presence of bacterial species including Streptococcus zooepidemicus, Staphylococcus intermedius and Staphylococcus epidermidis' these findings are similar to those reported by Keller and Hendrix (2005). These authors found that Streptococcus equi subspecies zooepidemicus was the most commonly isolated organism from ulcerative keratitis in horses, accounting for $33.3 \%$ of al isolates, followed by Pseudomonas aeruginosa (11.8\%) and Staphylococcus sp. (11.8\%) Additionally, their study confirmed that none of the bacterial microorganisms isolated exhibited resistance to antibiotics commonly used for the treatment of corneal ulcerations in horses.

Consequences of mycotic keratitis in horses are potentially severe and include rapidly progressive ulceration and perforation of the cornea (Brooks, 2004, Scotty, 2005 and Wada et al., 2010). Therefore, prompt identification of fungal etiology followed by appropriate therapy is highly desirable. The traditional method for confirmation of the causative fungal pathogen involves culturing organisms but several challenges exist with this method. Practical challenges to rapid diagnosis of fungal keratitis include the time needed to culture fungi (1-3 weeks), as well as potential alterations in the microbial populations in the culture swab which can occur during shipping (McLeod et al., 2005). Therefore, identification of a novel method that permits rapid diagnosis of the causative agent of equine fungal keratitis in affected patients is important to help practitioners to effectively address and treat affected patients. PCR combined with DNA sequencing is a promising alternative diagnostic tool for mycotic keratitis, as presented in this study.

Diagnosis of keratomycoses in humans using PCR has shown great potential (Vengayil et al., 2009 and Ferrer et al., 2011) but limited studies have been performed in horses to assess if PCR can also be used as an alternative diagnostic tool to culturing. To date only a single study analyzing PCR-based identification of fungal pathogens in infected corneal samples from horses has been conducted (Zeiss et al., 2013). While Zeiss et al's study focused on amplification of the ITS 1 region (amplifying the 18S rRNA gene) and using primers (D1 and D2) to amplify the 28S rRNA gene for fungal species identification. Our study examined the ability of conventional and seminested PCR to be used as a rapid diagnostic tool for equine mycotic keratitis by amplifying another conserved (ITS2/5.8S rRNA) region present in the fungal genome. When compared to the traditional culture method, PCR proved to be a superior diagnostic tool (which is in agreement with the conclusions drawn by Zeiss et al.). Using the culture method, a fungal pathogen was identified in only $16 \%$ of samples (2/ 12). In comparison, PCR successfully identified a fungal pathogen in $75 \%$ of samples (9/ 12). Furthermore, PCR was able to identify a greater spectrum of pathogenic fungi including fastidious organisms and organisms present in lower numbers within mixed infections than can be identified by culture (Petti, 2007). In most practices, fungal samples must be shipped and cultured directly from swabs within the recommended 2- to 24-h period (Chapin, 1995 and McLeod et al., 2005) otherwise fastidious fungi may die or vigorous fungi, which are not primary pathogens, may dominate the sample. Therefore, one significant limitation of the culture method is that a negative result does not rule out a fungal infection (McLeod et al., 2005). Another significant limitation of culturing is the length of time needed to obtain results. In this study, confirmation of pathogens via the conventional culture method required nearly 10 days to obtain results; PCR was able to provide a diagnosis within 8 hours.

PCR results obtained in our study support the notion that PCR is a promising diagnostic tool for equine keratitis. Though there were differences observed between results obtained via culturing versus PCR, the difference between culture and PCR results in our study may be explained by the fact that the culture positivity requires viable organisms, whereas a PCRbased test can detect both viable and nonviable organisms. A PCR test can theoretically be positive even if only a single copy of target DNA is present (Vengayil et al., 2009). PCR possesses additional advantages as a molecular diagnostic tool for equine keratitis including that PCR can detect DNA from either dead or living organisms, whereas only living organisms can grow in cultures. Even though routine fungal media are capable of detecting and growing common fungal pathogens, some unusual fungi may not be cultured in routine media. The use of panfungal primers in the PCR or nested PCR may alleviate this problem. Although various advantages have been attributed to PCR, due to its rapidity, the technique has some limitations. Among them is the difficulty in differentiating between active and latent infections, as well as distinguishing between viable and nonviable cells. Moreover, the DNA sequence has to be known in advance in order for appropriate primers to be designed (Vengayil et al., 2009).

While PCR holds great promise as a diagnostic tool for mycotic keratitis, the conventional culture method is still an important diagnostic technique for clinicians. The conventional culture method is an essential tool to identify causative fungi even if it may be less sensitive than the PCR. Moreover, culturing suspected pathogens allows for testing of antifungal susceptibility (to assess which antimicrobials are appropriate to use for treatment) and permits growth of specific fungal organisms not detectable with the primers used in the PCR assay. In 
addition, equipment and reagents necessary to perform the PCR are not readily available in all institutes, and the cost of the PCR is more expensive than the conventional culture method. However, as the present study demonstrates, PCR is a powerful tool that should be considered as a complimentary technique to use with culturing and can be used as an alternative diagnostic technique in cases where the causative pathogen cannot be identified by the routine culture method.

\section{REFERENCES}

Andrew, S.E.; Brooks, D.E.; Smith, P.J.; Gelatt, K.N.; Chmielewski, N.T. and Whittaker, C.J. (1998) Equine ulcerative keratomycosis: visual outcome and ocular survival in 39 cases (1987-1996). Equine Vet. J. 30, 109-116.

Andrew, SA. and Willis, AM. (2005): Diseases of the cornea and sclera. In: Equine Ophthalmology. (ed. Gilger BC). Elsevier Saunders, St Louis, MO, 157-251.

Balakrishnan, R. (2005): Fungal BLAST and Model Organism BLASTP Best Hits: new comparison resources at the Saccharomyces Genome Database (SGD). Nucleic Acids Res, 33(Database issue): p. D374-7.

Brooks, DE. (2009): Equine Keratomycosis: an international problem. Equine Veterinary Education 21: 243-251.

Brooks, DE. (2008): Corneal ulceration. In: Ophthalmology for the Equine Practitioner, 2nd edn. (ed. Brooks DE) Teton New Media, Jackson, Wyoming, 2008; 85-150.

Brooks, DE. (2004): Inflammatory stromal keratopathies: medical management of stromal keratomalacia, stromal abscesses, eosinophilic keratitis, and product keratopathy in the horse. Veterinary Clinics North America Equine Practice; 20: 345-360.

Brooks, DE. and Matthews, AG. (2007): Equine ophthalmology. In: Veterinary Ophthalmology, 4th edn (ed Gelatt KN). Blackwell Publishing, Ames, 2007; 1165-1274.

Chapin, K. (1995): General Issues in Clinical Microbiology, In: Clinical Microscopy Manual of Clinical Microbiology. (ed. Murray PR) American Society for Microbiology Press, Washington, DC, 38.

Clode, A.B. (2011): Diseases and surgery of the cornea. In: Equine Ophthalmology, 2nd edn., Ed: B.C. Gilger, W.B. Saunders, Philadelphia, Pennsylvania. pp 209-215.

Ferrer, C. (2001): Detection and Identification of Fungal Pathogens by PCR and by ITS2 and 5.8S Ribosomal DNA Typing in Ocular Infections. J. Clin Microbiol, 39(8):p 2873-2879.

Ferrer, C. and Alio, J.L. (2011): Evaluation of molecular diagnosis in fungal keratitis. Ten years of experience. Journal of Ophthalmic Inflammation and Infection. 1: 15-22.

Galàn, A.; Martín-Suárez, E.M.; Gallardo, J.M. and Molleda, J.M. (2009): Clinical findings and progression of 10 cases of equine ulcerative keratomycosis (2004-2007). Equine Vet. Educ. 21, 236-242.

Gaarder, JE.; Rebhun, WC. and Ball, MA. (1998): Clinical appearances, healing patterns, risk factors, and outcomes of horses with fungal keratitis: 53 cases (1978-1996) Journal of the American Veterinary Medical Association 1998; 213: 105-112.

Hamilton, H.I.; McLaughlin, S.A.; Whitley, E.M.; Gilger, B.C. and Whitley, R.D. (1994): Histological findings in corneal stromal abscesses of 11 horses: correlation with cultures and cytology. Equine Vet. J. 26, 448-453.

Hamor, RE. and Whelan, NC. (1999): Equine infectious keratitis. Veterinary Clinics North America Equine Practice, 15: 623-646.

Isenberg H. Aerobic Bacteriology. (1998): In: Essential Procedures for Clinical Microbiology (ed. Pezzlo M). American Society for Microbiology Press, Washington, DC, 37.

Keller, RL. and Hendrix, DV. (2005): Bacterial isolates and antimicrobial susceptibilities in equine bacterial ulcerative keratitis (1993-2004). Equine Vet J. 2005 May; 37(3):207-11.

Ledbetter, E.C.; Patten, V.H.; Scarlett, J.M. and Vermeylen, F.M. (2007): In vitro susceptibility patterns of fungi associated with keratomycosis in horses of the northeastern United States: 68 cases (1987-2006). J. Am. Vet. Med. Ass. 231, 1086-1091.

McLeod, SD.; Kumar, A. and Cevallos, V. (2005): Reliability of transport medium in the laboratory evaluation of corneal ulcers. American Journal of Ophthalmology; 140: 1027-1031.

Moore, CP.; Fales, WH.; Whittington, P. and Bauer, L. (1983): Bacterial and fungal isolates from Equidae with ulcerative keratitis. J. Am. Vet. Med. Assoc. 1983 Mar 15;182(6):600-3.

Nasisse, MP. and Nelms, S. (1992): Equine ulcerative keratitis. Veterinary Clinics North America Equine Practice 1992; 8: 537-555.

Petti, CA. (2007): Detection and identification of microorganisms by gene amplification and sequencing. Clinical and Infectious Diseases; 44: 1108-1114

Samuelson, D.A.; Andresen, T.L. and Gwin, R.M. (1984): Conjunctival fungal flora in horses, cattle, dogs, and cats. J. Am. Vet. Med. Ass. 184, 1240-1242.

Scotty N. Equine Keratomycosis. (2005): Clinical Techniques in Equine Practice; 4: 29-36. 
Thomas, P.A. (2003): Current perspectives on ophthalmic mycoses. Clin. Microbiol. Rev. 16, 730-797.

Turenne, CY.; Sanche, SE.; Hoban, DJ.; Karlowsky, JA. and Kabani, AM. (1999): Rapid Identification of Fungi by Using the ITS2 Genetic Region and an Automated Fluorescent Capillary Electrophoresis System. Journal of Clinical Microbiology, June, p. 1846-1851 Vol. 37, No. 6.

Wada, S.; Hobo, S. and Niwa, H. (2010): Ulcerative keratitis in thoroughbred racehorses in Japan from 1997 to 2008. Veterinary Ophthalmology; 13: 99-100.

Welch, P.M.; Gabal, M.; Betts, D.M.; Whelan, N.C. and Studer, M.E. (2000): In vitro analysis of antiangiogenic activity of fungi isolated from clinical cases of equine keratomycosis. Vet. Ophthalmol. 3, 145-151.

Vengayil, S.; Panda, A.; Satpathy, G.; Nayak, N.: Ghose, S.; Patanaik, D. and Khokhar, S. (2009): Polymerase Chain Reaction-Guided Diagnosis of Mycotic Keratitis: A Prospective Evaluation of Its Efficacy and Limitations. Investigative Ophthalmology \& Visual Science, January 2009, Vol. 50, No. 1

Zeiss, C.; Neaderland, M.; Yang, F.; Terwilliger, G. and Compton, S. (2013): Fungal polymerase chain reaction testing in equine ulcerative keratitis. Veterinary Ophthalmology, September 2013, Vol. 16, No. 5, 341-351.

\section{التحديد الجزيئى القائم على المنطقة ITS2 للفطريات الممرضة المسبية لتقرح القرنية فى الخيول \\ مها ابراهيم حامد، هارون محمد ، ونلى تونسند ، محمد نجبي سليم \\ Email: mahohzero@gmail.com}

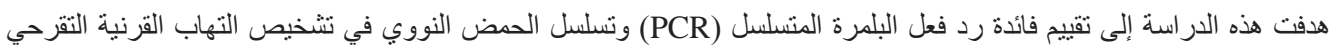

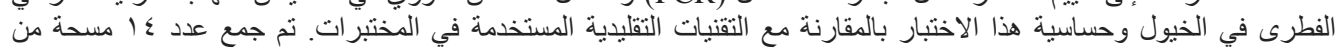

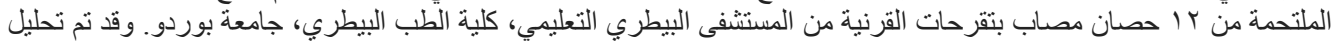

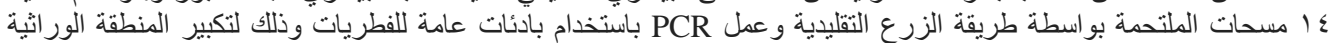

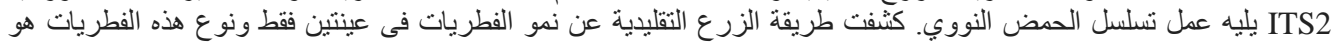

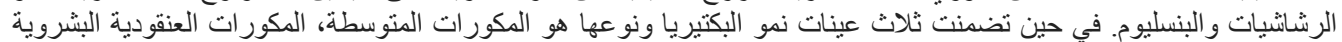

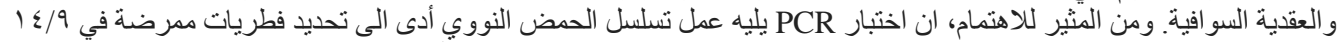

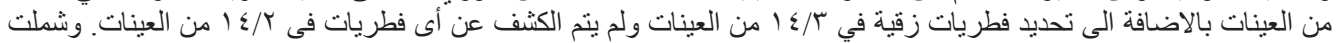

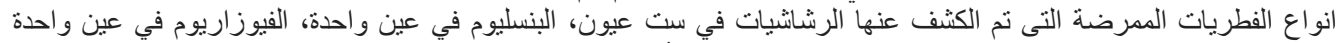

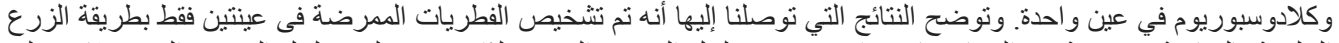

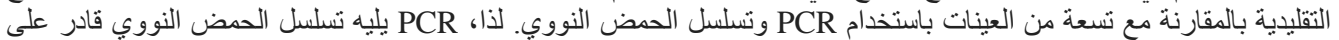

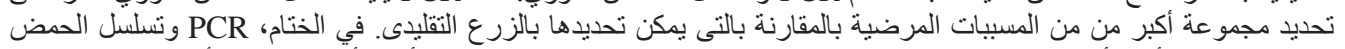

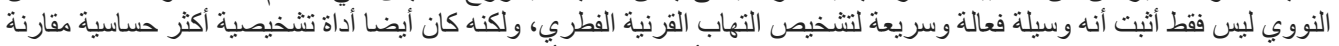

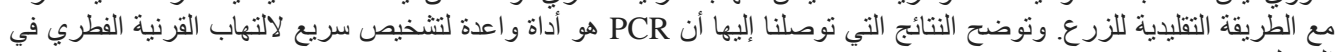
الخيول. 